\title{
Bovine mastitis: prevalence and antimicrobial susceptibility profile and detection of genes associated with biofilm formation in Staphylococcus aureus
}

\author{
Mastite bovina: prevalência, pefil de suscetibilidade aos \\ antimicrobianos e detecção de genes associados à formação de \\ biofilmes em Staphylococcus aureus
}

\author{
Valeska Paula Casanova ${ }^{1}$; Juceam Appio $^{1}$; Eduardo Kohl'; \\ Tais Regina Michaelsen ${ }^{1}$; Daniel Santos Paim²; Thaís Regina Brunetto ${ }^{1}$; \\ Débora da Cruz Payão Pellegrini'; ; Paulo Eduardo Bennemann; \\ Silvana Giacomini Collet ${ }^{4}$; Lilian Kolling Girardini ${ }^{*}$
}

\begin{abstract}
Brazil currently ranks as one of the world leaders in food production and exportation. This scenario encourages the development of animal and plant health programs to ensure the production of safe food, helping the country to become an international provider of food for excellence. However, some health problems in dairy production, such as mastitis, have garnered increasing concern. This study aimed to estimate the prevalence of bovine mastitis in select properties located in the western Santa Catarina region, to assess the susceptibility profile to antimicrobial agents used for treatment and to check for the presence of genes (icaA and icaD) associated with biofilm formation in Staphylococcus aureus. In 148 milk samples collected, $72.97 \%$ had bacterial growth $(\mathrm{n}=108)$. Among the isolated microorganisms, $21.62 \%(\mathrm{n}=32)$ were classified as Staphylococcus aureus, $18.91 \%(\mathrm{n}=28)$ as Staphylococcus sp. coagulase negative, $7.43 \%(\mathrm{n}=11)$ as Corynebacterium sp., 6.76\% $(\mathrm{n}=10)$ as Staphylococcus sp. coagulase positive, $5.41 \%(\mathrm{n}=8)$ as Nocardia sp. and $12.83 \%(\mathrm{n}=19)$ classified in different bacterial genera. Among the isolates submitted for antimicrobial susceptibility testing, it was observed that $8.95 \%$ $(\mathrm{n}=6 / 67)$ had resistance to amoxicillin, 8.04\% $(\mathrm{n}=7 / 87)$ to ampicillin, 5.88\% $(\mathrm{n}=5 / 85)$ to cephalothin, $3.40 \%(n=3 / 88)$ to ceftiofur and enrofloxacin, $20.45 \%(n=18 / 88)$ to streptomycin, $17.04 \%(n=15 / 88)$ to gentamicin and lincomycin, $31.81 \%(\mathrm{n}=28 / 88)$ to neomycin, $14.94 \%(\mathrm{n}=13 / 87)$ to penicillin and $25 \%(n=22 / 88)$ to tetracycline. Staphylococcus sp. coagulase negative isolates showed higher multidrug resistance when compared to those of $S$. aureus and Staphylococcus sp. coagulase positive. Thirty-one strains of $S$. aureus isolates were genotypically tested by polymerase chain reaction (PCR), yielding a positive result for the icaA gene in $83.87 \%$ of the samples, $80.64 \%$ positive for $i c a D$ and $74.19 \%$ of these showed both genes. The results reinforce the importance of controlling this disease by adopting strict hygiene protocols and disinfection of equipment used for milking and the prescription of appropriate therapies to clinical and subclinical cases of mastitis, as well as evaluating not only the susceptibility profile of isolates but also the biofilm formation capacity.
\end{abstract}

Key words: Antimicrobial resistance. Biofilm. Mastitis. Staphylococcus aureus.

1 Discentes do curso de Medicina Veterinária, Universidade do Oeste de Santa Catarina, UNOESC, Xanxerê, SC, Brasil. E-mail: valeskapaula.vet@gmail.com; juceam_appio@hotmail.com; kohleduardo@gmail.com; taismichaelsen@yahoo.com.br; thais_ brunetto@hotmail.com

2 Discente do curso de Mestrado, Universidade Federal do Rio Grande do Sul, UFRGS, Porto Alegre, RS, Brasil. E-mail: daniel_ paim20@hotmail.com

3 Prof $f^{a}$ Universidade Federal do Pampa, UNIPAMPA, Uruguaiana, RS, Brasil. E-mail: deborapellegrini@unipampa.edu.br

4 Profs., UNOESC, Xanxerê, SC, Brasil.E-mail: paulo.bennemann@unoesc.edu.br; silvana.collet@unoesc.edu.br; lilian.kolling@ unoesc.edu.br

Author for correspondence 


\section{Resumo}

O Brasil situa-se hoje como um dos líderes mundiais em produção e exportação de alimentos. Este cenário incita a elaboração de programas de sanidade animal e vegetal que garantam a produção de alimentos seguros, contribuindo para que o país se torne um fornecedor internacional de alimentos por excelência. Entretanto, alguns problemas sanitários na produção leiteira, como a mastite, têm acarretado crescentes preocupações. O presente estudo teve como objetivo estimar a prevalência de mastite bovina em algumas propriedades localizadas na região Oeste de Santa Catarina, avaliar o perfil de suscetibilidade aos antimicrobianos empregados para tratamento e verificar a presença de genes (icaA e icaD) associados à formação de biofilmes em Staphylococcus aureus. Em 148 amostras de leite coletadas, $72,97 \%$ apresentaram crescimento bacteriano $(\mathrm{n}=108)$. Dentre os micro-organismos isolados, $21,62 \%(\mathrm{n}=32)$ foram classificados como Staphylococcus aureus, $18,91 \%(\mathrm{n}=28)$ como Staphylococcus sp. coagulase negativa, 7,43\% ( $\mathrm{n}=11)$ como Corynebacterium sp., 6,76\% $(\mathrm{n}=10)$ como Staphylococcus sp. coagulase positiva, $5,41 \%(\mathrm{n}=8)$ como Nocardia sp. e 12,83\% $(\mathrm{n}=19)$ classificados em diferentes gêneros bacterianos. Dentre os isolados submetidos ao teste de suscetibilidade aos antimicrobianos, observou-se 8,95\% $(\mathrm{n}=6 / 67)$ de resistência à Amoxicilina, 8,04\% $(\mathrm{n}=7 / 87)$ à Ampicilina, 5,88\% $(\mathrm{n}=5 / 85)$ à Cefalotina, $3,40 \%(n=3 / 88)$ ao Ceftiofur e Enrofloxacina, $20,45 \%(n=18 / 88)$ à Estreptomicina, $17,04 \%(n=15 / 88)$ à Gentamicina e Lincomicina, 31,81\% $(n=28 / 88)$ à Neomicina, $14,94 \%(n=13 / 87)$ à Penicilina e $25 \%(n=22 / 88)$ à Tetraciclina. Ainda, os isolados de Staphylococcus sp. coagulase negativa apresentaram maior multirresistência quando comparados aos isolados de S. aureus e Staphylococcus sp. coagulase positiva. Trinta e uma amostras de $S$. aureus isoladas foram testadas genotipicamente pela técnica de reação em cadeia da polimerase (PCR), obtendo-se resultado positivo em $83,87 \%$ das amostras para o gene IcaA, $80,64 \%$ positivas para IcaD e $74,19 \%$ dessas apresentaram ambos os genes. Os resultados obtidos demonstram a importância do controle desta enfermidade pela adoção de protocolos rígidos de higiene e desinfecção dos equipamentos utilizados na ordenha e também a prescrição de terapias adequadas aos casos clínicos e subclínicos de mastite, bem como a avaliação não apenas do perfil de suscetibilidade dos isolados, mas também a capacidade de formação de biofilmes.

Palavras-chave: Biofilme. Mastite. Resistência aos antimicrobianos. Staphylococcus aureus.

\section{Introduction}

Brazil is considered one of the largest producers of milk, and the South and Southeast regions are the main producers. Santa Catarina state is the sixth largest national milk producer, and approximately $70 \%$ of Santa Catarina's production is concentrated in the western region (IBGE, 2013), playing an important role for small farms from an economic and social point of view. Milk production is responsible for direct and indirect job creation and income to farmers, thus becoming one of the most important activities related to rural development.

In this context, the quality of milk is essential for the competitiveness of dairy farming; quality is influential in both the manufacture of dairy products and derivatives as well as in consumer preference. Despite advances in the dairy cattle industry, one of the barriers to the development and consolidation of the dairy industry in Brazil is the quality of the milk (FAGUNDES; OLIVEIRA, 2004).
Some health problems in the dairy industry have caused increasing concerns. Mastitis is characterized by an inflammation of the mammary gland, usually infectious in nature, in which bacteria are the main etiological agents. This condition affects dairy cattle and leads to losses resulting from the reduction in milk production, animal value depreciation, limiting the production of derivative products, milk disposal, spending on medicines, veterinary fees, labor augmentation, early disposal of females, among others. Furthermore, the possibility of transmission of pathogenic microorganisms and/or their toxins or transfer of antibiotic residue through the milk pose severe risks to public health (FORSYTHE, 2002).

Staphylococcus aureus is the main agent associated with the contagious bovine mastitis. Many chronic infections caused by this pathogen are related to the formation of biofilms; this feature hinders the action of macrophages, and it also provides resistance to various antibiotics and 
encourages the residual persistence of these in the environment (BOYEN et al., 2009). Several genes are involved in the individual capacity of biofilm formation, highlighting the icaA and icaD genes (MELCHIOR et al., 2009).

Antibiotic use in the treatment of mastitis is frequent; however, there has been an increase in the bacterial resistance index (BRITO et al., 2001). This fact reinforces the importance of adopting appropriate treatment protocols with effective medicines, which must be selected from phenotypic and genotypic testing (COELHO et al., 2007).

This study aimed to estimate the prevalence of bovine mastitis in dairy farms located in the western region of Santa Catarina to determine the main isolated microorganisms, to evaluate the susceptibility front of the main antibiotics used in the treatment of this disease, as well as to check for the presence of genes associated with biofilm formation in S. aureus strains.

\section{Material and Methods}

\section{Place of execution and collection of material}

A total of 148 individual milk samples were collected from 148 animals on 12 farms located in the western region of Santa Catarina. All properties analyzed had adopted the mechanics milking system, and the herds were composed of primiparous and pluriparous cows of different races and different stages of lactation.

All procedures performed in the collection, transportation of samples, isolation and identification of the etiologic agents of mastitis followed the recommendations of National Mastitis Council (2004). Prior to harvest, the ceilings were individually cleaned using water and disposable paper towels, disregarding the three foremilk on black background mug to evaluate for the presence of clinical mastitis. The CMT (California Mastitis Test) was performed to confirm the presence of subclinical mastitis without the evaluation of different degrees. Prior to taking the samples, the animal teats were disinfected with cotton that was soaked with $70 \%$ ethanol. Three milk jets from each teat were collected and stored in sterile vials, and CMT testing was performed on sample from each animal. The vials were opened only at the moment of harvest; they were opened in a horizontal position to avoid contaminants entering into the container. The samples were duly identified and kept under refrigeration $\left(4\right.$ to $8^{\circ} \mathrm{C}$ ) during transport to the microbiology laboratory for further analysis.

\section{Isolation and bacterial identification}

The cultivation of the samples was performed on blood agar supplemented with 5\% defibrinated sheep blood, MacConkey agar and Sabouraud agar. The plates were incubated at $36^{\circ} \mathrm{C}$ for 24 to 48 hours, the microorganisms were identified according to the morphological and staining characteristics according to the description presented by Markey et al. (2013). After incubation, the colonies were evaluated according to the morphological characteristics and hemolysis patterns. Gram-staining and catalase tests were performed, the latter separating the likely Staphylococcus and Micrococcus strains (catalasepositive) from Streptococcus and Enterococcus strains (catalase-negative); this also assisted in the identification of strains of Corynebacterium sp. The isolates that were positive for the catalase test were submitted to the coagulase test tube, acetoin production and growth on agar salt mannitol. The isolates that were negative in the catalase test underwent the esculin test, bile esculin test, Pyrrolidonyl arylamidase test, hippurate, CAMP and $\mathrm{NaCl} 6.5 \%$ to characterize the species. For isolates that presented as Gram-negative, the tests used were oxidase, OF, motility, indole, VM, VP, citrate, urea, gelatin, TSI, among others.

\section{Antimicrobial susceptibility testing}

Once the strains had been isolated and identified, susceptibility testing to antibiotics was performed by 
the disk diffusion method of Kirby-Bauer modified in accordance with the recommendations of the veterinary CLSI (2008) to evaluate the susceptibility profile of the front of these microorganisms compared to antimicrobials commonly used in treatment of mastitis. The following antimicrobials classes were tested: beta-lactams - penicillin (10 $\mathrm{IU})$, amoxicillin $(10 \mu \mathrm{g})$, ampicillin $(10 \mu \mathrm{g})$, oxacillin $(1 \mu \mathrm{g})$, cephalothin $(30 \mu \mathrm{g})$ and ceftiofur $(30 \mu \mathrm{g})$; aminoglycosides - streptomycin $(10 \mu \mathrm{g})$, gentamicin $(10 \mu \mathrm{g})$ and neomycin $(10 \mu \mathrm{g})$; lincosamides lincomycin $(2 \mu \mathrm{g})$; fluoroquinolones - enrofloxacin $(5 \mu \mathrm{g})$; sulfonamides - sulfazotrim $(25 \mu \mathrm{g})$ and tetracycline - tetracycline $(30 \mu \mathrm{g})$. All isolates were stored on nutrient agar and then stored at $-20^{\circ} \mathrm{C}$ in $\mathrm{BHI}$ broth and glycerol in a 8:2 ratio, respectively.

\section{Presence of genes associated with biofilm formation}

Isolates of Staphylococcus aureus were characterized by the presence of genes associated with the formation of biofilms (icaA and icaD) by PCR. The DNA extraction was performed according to the description of Rademaker and De Bruijn (1997).
For PCR execution, $4 \mu \mathrm{l}$ of DNA suspension were applied in $11 \mu \mathrm{l}$ of mix containing $20 \mathrm{pmol} / \mu \mathrm{l}$ of each primer, $2.5 \mathrm{mM}$ of the deoxyribonucleotides, $1.5 \mu \mathrm{L} 10 \times$ PCR buffer $(750 \mathrm{mM}$ Tris $\mathrm{HCl}(\mathrm{pH} 8.8)$ $200 \mathrm{mM}\left(\mathrm{NH}_{4}\right)_{2} \mathrm{SO}_{4}$ and $0.1 \%$ Tween 20$)$ and $0.3 \mu \mathrm{L}$ Taq DNA Polymerase $5 \mathrm{U} / \mathrm{uL}$. This mixture was brought to the thermocycler with cyclical conditions suggested by Vasudevan et al. (2003). Modifications were as follows: initial denaturation at $94^{\circ} \mathrm{C}$ for 2 min, 30 cycles of denaturation at $94^{\circ} \mathrm{C}$ for $45 \mathrm{~s}$, annealing at $49.8^{\circ} \mathrm{C}$ for $45 \mathrm{~s}, 1 \mathrm{~min}$ extension at $72^{\circ} \mathrm{C}$ and a final extension of $7 \mathrm{~min}$ at $72^{\circ} \mathrm{C}$. In all reactions, negative control samples were used (without target DNA), and the positive control was S. aureus strain ATCC 25923. The banding patterns were evaluated using a 100 bp molecular weight marker.

The results of the PCRs were checked on $1.5 \%$ agarose gel, stained with ethidium bromide (2 $\mu \mathrm{g} / \mathrm{ml}$, Sigma, St. Louis, USA), visualized on a transilluminator, and the image was captured and digitized by the Kodak 2200 system (Rochester, New York, USA). The primers for detecting icaD and icaA genes in $S$. aureus isolates are described in Table 1.

Table 1. Oligonucleotide primers used for detection of icaD and icaA genes in Staphylococcus aureus isolates.

\begin{tabular}{lccc}
\hline Primer & Sequence $\left(\mathbf{5}^{\prime} \mathbf{- 3}^{\prime}\right.$ ) & Fragment length & Reference \\
\hline IcaA F & CCT AAC TAA CGA AAG GTA G & $1315 \mathrm{bp}$ & Vasudevan et al., 2003 \\
IcaA R & AAG ATA TAG CGA TAA GTG C & $1315 \mathrm{bp}$ & Vasudevan et al., 2003 \\
IcaD F & AAA CGT AAG AGA GGT GG & $381 \mathrm{bp}$ & Vasudevan et al., 2003 \\
IcaD R & GGC AAT ATG ATC AAG ATA C & $381 \mathrm{bp}$ & Vasudevan et al., 2003 \\
\hline
\end{tabular}

\section{Statistical analysis}

The descriptive statistics analysis (absolute and relative frequencies) was realized using Statistical Package for the Social Sciences (SPSS) software version 20 .

\section{Results}

Of the 148 samples analyzed, 72.97\% $(\mathrm{n}=$ 108) showed bacterial growth. Of these, $21.62 \%$ $(\mathrm{n}=32$ ) were classified as $S$. aureus, followed by Staphylococcus sp. coagulase negative (CNS), Corynebacterium sp., Staphylococcus sp. coagulase positive (SCP), and other agents described in Table 
2. There were no microbiological growth in forty samples taken $(27.03 \%)$, and only one sample showed growth of yeast cells in Sabouraud agar.

The highest resistance rates were observed for the antibiotics neomycin (31.81\%, $\mathrm{n}=28 / 88)$, tetracycline $(25 \%, \mathrm{n}=22 / 88)$, streptomycin
$(20.45 \%, \mathrm{n}=18 / 88)$, gentamicin and lincomycin $(17.04 \%, \mathrm{n}=15 / 88)$ and penicillin $(14.94 \%, \mathrm{n}=$ 13/87). The bacterial isolates expressed greater sensitivity to ceftiofur and enrofloxacin principles (96.59\% susceptibility, $\mathrm{n}=3 / 88)$ and cephalothin (94.11\%, $\mathrm{n}=80 / 85)$.

Table 2. Frequency and percentage (\%) of microorganisms isolated in milk samples collected from cows with positive CMT.

\begin{tabular}{ccc}
\hline Isolated microorganisms & Frequency & $\%$ \\
\hline No growth & 40 & $27.03 \%$ \\
Staphylococcus aureus & 32 & $21.62 \%$ \\
Ctaphylococcus sp. coagulase negative (CNS) & 28 & $18.92 \%$ \\
Corynebacterium sp. & 11 & $7.43 \%$ \\
Staphylococcus sp. coagulase positive (SCP) & 10 & $6.76 \%$ \\
Nocardia sp. & 8 & $5.41 \%$ \\
Streptococcus equinus & 5 & $3.38 \%$ \\
Streptococcus uberis & 4 & $2.70 \%$ \\
Enterobacter aerogenes & 3 & $2.03 \%$ \\
Yeast growth & 1 & $0.68 \%$ \\
Enterobacter sp. & 1 & $0.68 \%$ \\
Enterococcus sp. & 1 & $0.68 \%$ \\
Escherichia coli & 1 & $0.68 \%$ \\
Streptococcus alactolyticus & 1 & $0.68 \%$ \\
Streptococcus dysgalactiae & 1 & $0.68 \%$ \\
Streptococcus acidominimus & 1 & $0.68 \%$ \\
\hline Total & 148 & $100 \%$ \\
\hline
\end{tabular}

All isolates of Staphylococcus aureus presented sensitivity to ampicillin, cephalothin and ceftiofur; higher levels of resistance were observed in the principles neomycin $(37.5 \%, \mathrm{n}=12 / 32)$, gentamicin $(28.12 \%, \mathrm{n}=9 / 32)$ and tetracycline $(12.5 \%, \mathrm{n}$ $=4 / 32$ ), which are principles used frequently in systemic and topical treatments.

Although $S$. aureus isolates are among the most prevalent and pathogenic in this study, CNS isolates showed greater resistance to the total number of classes of antimicrobials evaluated when compared to $S$. aureus and SCP (Table 3).

Multidrug-resistant isolates in this study were defined as those isolates that were resistant to three or more antimicrobial classes, according to Schwarz et al. (2010). One Enterococcus sp. isolate, nine CNS and three $S$. aureus presented multidrug resistance profiles to antibiotics, and some strains expressed resistance to five evaluated classes. Multidrug resistance profiles are detailed in Table 3.

Of the $31 \mathrm{~S}$. aureus isolates evaluated for the presence of icaA and icaD genes associated with formation of biofilm, $83.87 \%$ had the icaA gene, $80.64 \%$ icaD the gene and $74.19 \%$ were positive for both genes. The DNA extraction of one isolate could not be performed; thus, it was not submitted for PCR analysis. 
Table 3. Multidrug resistance profiles to antimicrobial presented by microorganisms in milk samples.

\begin{tabular}{cccc}
\hline Microorganism & Multidrug resistance profile & Isolates (n) & Resistant classes \\
\hline Enterococcus sp. & STR/LIN/NEO/PEN/SUT/TET & 1 & 5 \\
& AMO/AMP/CEF/CTF/ENR/STR/LIN/PEN/TET & 1 & 5 \\
& CTF/EST/GEN/LIN/NEO/TET & 1 & 5 \\
& AMO/AMP/CEF/STR/LIN/PEN/TET & 1 & 4 \\
S. coagulase negative (CNS) & CEF/CTF/EST/GEN/NEO/TET & 1 & 4 \\
& NEO/PEN/SUT/TET & 1 & 4 \\
& AMO/AMP/LIN/PEN/TET & 1 & 3 \\
AMO/CEF/LIN/PEN/TET & 1 & 3 \\
ENR/GEN/NEO/SUT aureus & LIN/NEO/OXA & 1 & 3 \\
& AMO/SUT/TET & 1 & 3 \\
S. coagulase positive (SCP) & ENR/GEN/TET & 1 & 3 \\
STR/LIN/TET & 1 & 3 \\
\hline
\end{tabular}

$\mathrm{AMO}=$ Amoxicillin, $\mathrm{AMP}=$ Ampicillin, $\mathrm{CEF}=$ Cefalotin, $\mathrm{CTF}=$ Ceftiofur, $\mathrm{ENR}=$ Enrofloxacin, $\mathrm{STR}=$ Streptomycin, GEN=Gentamicin, LIN= Lincomycin, NEO=Neomycin, $\mathrm{PEN}=$ Penicillin, $\mathrm{SUT}=$ Sulfazotrim, $\mathrm{TET}=$ Tetracycline .

\section{Discussion}

Of all the obtained samples, 108 showed bacterial growth $(72.97 \%)$, which reveals a high prevalence of mastitis in the sampled herds. As reported in Zanela et al. (2006), the high mastitis levels are directly linked to hygienic conditions of the property and animal health, including flaws in the cleaning of pickets, management problems and milking environment, as well as failures in nutrition of animals.

Of the 148 isolates, $40(27.03 \%)$ showed no microbial growth. Although bacterial isolation is considered the gold standard technique for characterizing the etiology of mastitis, some samples of milk with clinical and subclinical mastitis can present negative results (MAKOVEC; RUEGG, 2003). This fact can be justified due to the intermittent elimination of the agent in chronic infections or from their reduced presence in milk (SEARS et al., 1990).

S. aureus was the most prevalent agent (21.62\%) in this study. Similar data were described by Ferreira et al. (2007) and Martins (2010) in which both observed a $21.5 \%$ of prevalence of $S$. aureus strains isolated in cases of subclinical mastitis. In both studies, the evaluated properties had adopted similar managements as the use of mechanical milking at different stages of lactation. They were unable to evaluate whether there was any pattern in temporal distribution, such as seasonality between the isolated microorganisms, as the samples were taken at different times of the year.

S. aureus is considered to be the most important microorganism in contagious mastitis in cattle. Despite nearly a $22 \%$ prevalence, this percentage may be determined to be low when compared to the ratios reported in other studies. Unakal and Kaliwal (2010) evaluated 105 samples of milk from different dairy farms and reported a prevalence of approximately $65 \%$ for this agent; other authors also reported a high prevalence (WAAGE et al., 1999).

The second most prevalent agent was the CNS, which highlights the importance of this microorganism as the etiologic agent of mastitis in this study. Amaral et al. (2003) emphasize the importance of infection in the mammary gland as a 
result of CNS, which may be responsible for longterm processes that compromise the composition and milk production. In similar studies, the authors found CNS as the most prevalent agent (FREITAS et al., 2005; TENHAGEN et al., 2006). A similar result was found by Marques et al. (2013), who analyzed 272 samples of milk from eight properties of the South Fluminense region of the state of Rio de Janeiro and found 250 isolates of Staphylococcus spp., from which 58\% (145/250) were CNS and $42 \% \quad(105 / 250) \quad$ Staphylococcus sp. coagulase positive. Of these, $36.2 \%(38 / 105)$ were identified as $S$. aureus.

In relation to antimicrobial susceptibility testing, high bacterial resistance rates were observed when evaluating antibiotics neomycin, tetracycline, streptomycin, gentamicin, lincomycin and penicillin. Although some studies show higher resistance rates (RABELLO et al., 2005; ZAFALON et al., 2008; UNAKAL; KALIWAL, 2010), this may be related to the more frequent use of these agents and/or the presence of genes associated with biofilm formation (MELCHIOR et al., 2006a).

Oliveira (2002) showed a high percentage of resistance of Staphylococcus sp. samples isolated from animals with subclinical mastitis; the resistance was especially present in penicillin and tetracycline. These authors noted the incorrect and indiscriminate use of these antimicrobials was responsible for this situation. However, in the present study, there was a higher percentage of in vitro resistance to neomycin, gentamicin and streptomycin. These antibiotics are widely used in dairy cattle to treat various conditions (NETTO et al., 2005), especially uterine infections, often in under-dosing due to the application in the form of infusion. In addition, several drugs of intramammary application have these three antimicrobials in their compositions, which may have contributed to the increase in resistance rates, especially when therapy is administered incorrectly.

Although S. aureus was the most frequently isolated agent, a result of extreme importance in this study was that CNS multidrug-resistant isolates compared to S. aureus and SCP. Rajala-Schultz et al. (2004), in a study evaluating 202 bacterial agents, showed a prevalence of $78 \%$ of CNS, and of these, $44 \%$ were resistant to more than one antibiotic. Similarly, Medeiros et al. (2009) also found CNS isolated from cows with subclinical mastitis with resistance profiles for more than eight different antimicrobial compounds. This finding reinforces the importance of this agent in cases of mastitis because the multidrug resistance to treatment may be associated with persistence of agents in the herd, leading to cases of chronic infection as well as predisposing to further infection.

Human diseases caused by $S$. aureus multiresistant strains from animals are found worldwide, which makes it essential to assess the susceptibility of this isolated microorganism in relation to antibiotics. The increasing number of globally distributed multi-drug resistant isolates from mastitis cases is a serious problem that causes increases in treatment costs and a greater likelihood of transmission of this disease due to the persistence of bacteria in the herds (SABOUR et al., 2004; FAGUNDES; OLIVEIRA, 2004). The importance of carrying out accurate diagnosis through isolation and identification of agents in laboratories and in vitro analysis of antimicrobial susceptibility is emphasized, mainly to prescribe the most appropriate therapy and so reduce the risk of bacterial multidrug resistance.

Most $S$. aureus isolates evaluated demonstrated the presence of one or both genes associated with biofilm formation. The ability of the bacterial agents to form a biofilm is directly related to microbial adhesion to a variety of surfaces, allowing it to be found on the milking environment, including the udder and teats of the animals, blowers, milking machines and utensils used in the cleaning before and after milking. These factors make it difficult to control mastitis in dairy farms (LEE et al., 2012). In the biofilm, bacteria remain less susceptible to the action of antibiotics and innate host response by preventing phagocytosis, as well as favoring 
the maintenance and the persistence of the bacteria in the environment. Melo (2012) investigated the presence of icaA and icaD (genes responsible for the synthesis of the biofilm) in $94 \mathrm{~S}$. aureus strains isolated from milk samples derived from cattle with subclinical mastitis and confirmed that $95.7 \%$ had both genes. Vasudevan et al. (2003) also analyzed $S$. aureus strains isolated from bovine milk samples with subclinical mastitis and found $100 \%$ were positive for icaA and icaD, thus confirming the potential of these genes as virulence factor in the pathogenesis of mastitis of ruminants. The high presence of icaA and icaD genes in $S$. aureus isolates emphasizes the importance in controlling mastitis caused by this agent because once formed the biofilm, the infection is likely to become chronic and difficult to treat.

Despite the high presence of icaA and icaD genes, only three $S$. aureus isolates showed a multidrug resistance profile with the disk diffusion test. Detection of the icaA and icaD genes in most tested isolates demonstrates that these strains may come to form biofilm once activation occurs. Thus, even when the isolates presented sensitivity to various antibiotics, this microorganism can remain protected from the action of these by biofilms. The discrepancy between the results of in vitro antimicrobial susceptibility and the in vivo cure obtained by antimicrobial therapies highlights the importance of biofilm formation in vivo by $S$. aureus, which in turn has resulted in disappointing cure rates, especially in long term infections (MELCHIOR et al., 2006b). Melchior et al. (2011) evaluated a collection of $S$. aureus isolates from bovine mastitis cases by antimicrobial susceptibility extended to biofilm test (EBS) and found the duration of therapy as the most important factor for the bovine mastitis cure rate. However, this same article emphasized that treatment should be recommended only in recent $S$. aureus infections.

\section{Conclusion}

Despite the role that the high prevalence of bovine mastitis directly plays in the sustainability and viability of dairy cattle, the occurrence of multidrug resistance coupled with gene expression capacity that is associated with the formation of biofilms reinforces the importance of controlling this disease by adopting strict protocols of hygiene and disinfection of equipment used in milking. Furthermore, it also aids in prescribing therapies appropriate to the clinical and subclinical mastitis, especially in $S$. aureus infections.

Although high levels of susceptibility have been found in $S$. aureus, the observed resistance to neomycin, gentamicin, and tetracycline antibiotics is of concern because they are frequently used in treatment protocols for mastitis. Furthermore, the presence of icaD and icaA genes in most isolates emphasizes the importance to assess both the susceptibility profile of the isolates and the biofilm formation capacity.

The presence of nine CNS strains with multidrug resistance profiles is extremely important not only for the control of bovine mastitis but also with regards to public health because milk is a major source of income for many producers; it is also an indispensable food for much of the population.

\section{References}

AMARAL, L.; ROSSI JUNIOR, O. D.; NADER FILHO, A.; FERREIRA, F. I.; BARROS, L. S. Ocorrência de Staphylococcus sp. em água utilizada em propriedades leiteiras do estado de São Paulo. Arquivo Brasileiro de Medicina Veterinária e Zootecnia, Belo Horizonte, v. 55, n. 5, p. 620-623, 2003.

BOYEN, F.; EECKHAUT, V.; VAN IMMERSEEL, F.; PASMANS, F.; DUCATELLE, R.; HAESEBROUCK, F. Quorum sensing in veterinary pathogens: Mechanisms, clinical importance and future perspectives. Veterinary Microbiology, Barcelona, v. 135, n. 3-4, p. 187-195, 2009. 
BRITO, M. A. V. P.; BRITO, J. R. F.; SILVA, M. A. S.; CARMO, R. A. Concentração mínima inibitória de dez antimicrobianos para amostras de Staphylococcus aureus isoladas de infecção intramamária bovina. Arquivo Brasileiro de Medicina Veterinária e Zootecnia, Belo Horizonte, v. 53, n. 5, p. 10-17, 2001.

CLSI. Performance standards for antimicrobial disk and dilution susceptibility tests for bacteria inaccessible from animals. $3^{\text {th }}$ ed. Approved Standard. CLSI document M31-A3. v. 28, n. 8, 2008. 116 p.

COELHO, S. M. O.; MORAES, R. A. M.; SOARES, L. C.; PEREIRA, I. A.; GOMES, L. P.; SOUZA, M. M. S. Mapeamento do perfil de resistência e detecção do gene mecA em Staphylococcus aureus e Staphylococcus intermedius oxacilina-resistentes isolados de espécies humanas e animais. Ciência Rural, Santa Maria, v. 37, n. 1, p. 195-200, jan./fev. 2007.

FAGUNDES, H.; OLIVEIRA, C. A. F. Infecções intramamárias causadas por Staphylococcus aureus e suas implicações em saúde pública. Ciência Rural, Santa Maria, v. 34, n. 4, p. 1315-1320, 2004.

FERREIRA, J. L.; LINS, J. L. H. A.; CAVALCANTE, T. V.; MACEDO, N. A.; BORJAS, A. R. Prevalência e etiologia da mastite bovina - município de Teresina, Piauí. Ciência Animal Brasileira, Goiânia, v. 8, n. 2, p. 261-266, 2007.

FORSYTHE, S. J. Microbiologia da segurança alimentar. Porto Alegre: Artmed, 2002. 424 p.

FREITAS, M. F. L.; PINHEIRO JUNIOR, J. W.; STAMFORD, T. L. M.; RABELO, S. S. A.; SILVA, D. R.; SILVEIRA FILHO, V. M.; SANTOS, F. G. B.; SENA, M. J.; MOTA, R. A. Perfil de sensibilidade antimicrobiana in vitro de Staphylococcus coagulase positivos isolados de leite de vacas com mastite no agreste do estado de Pernambuco. Arquivos do Instituto Biológico, São Paulo, v. 72, n. 2, p. 171-177, 2005.

INSTITUTO BRASILEIRO DE GEOGRAFIA E ESTATÍSTICA - IBGE. Estatística da produção pecuária. Rio de Janeiro: IBGE, 2013. Disponível em: <http:// www.ibge.gov.br>. Acesso em: 2 out. 2013.

LEE, S. H. I.; CAMARGO, C. H.; GONÇALVES, J. L.; CRUZ, A. G.; SARTORI, B. T.; MACHADO, M. B.; OLIVEIRA, C. A. F. Characterization of Staphylococcus aureus isolates in milk and milking environment from small-scale dairy farms os São Paulo, Brazil, using pulsefield electrophoresis. Journal of Dairy Science, Madison, v. 95, n. 12, p. 7377-7383, 2012.
MAKOVEC, J. A.; RUEGG, P. L. Results of milk samples submited for microbiological examination in Wisconsin from 1994 to 2001. Journal of Dairy Science, Madison, v. 86, n. 11, p. 3466-3472, 2003.

MARQUES, V. F.; SOUZA, M. M. S.; MENDONÇA, E. C. L.; ALENCAR, T. A.; PRIBUL, P. R.; COELHO, S. M. O.; LASAGNO, M.; REINOSO, E. B. Análise fenotípica e genotípica da virulência de Staphylococcus spp. e de sua dispersão clonal como contribuição ao estudo da mastite bovina. Pesquisa Veterinária Brasileira, Brasília, v. 33, n. 2, p. 161-170, 2013.

MARKEY, B. K.; LEONARD, F. C.; ARCHAMBAULT, M.; CULLINANE, A.; MAGUIRE, D. Clinical veterinary microbiology. London: MOSBY Elsevier, 2013. 901 p.

MARTINS, R. P.; GONÇALINA, J. A.; NAKAZATO, L.; DUTRA, V.; ALMEIDA FILHO, E. S. Prevalência e etiologia infecciosa da mastite bovina na microrregião de Cuiabá, MT. Ciência Animal Brasileira, Goiânia, v. 11, n. 1, p. 181-187, 2010.

MEDEIROS, E. S.; MOTA, R. A.; SANTOS, M. V.; FREITAS, M. F. L.; PINHEIRO JUNIOR, J. W.; TELES, J. A. A. Perfil de sensibilidade microbiana in vitro de linhagens de Staphylococcus spp. isoladas de vacas com mastite subclínica. Pesquisa Veterinária Brasileira, Brasília, v. 29, n. 7, p. 569-574, 2009.

MELCHIOR, M. B.; FINK-GREMMELS, J.; GAASTRA, W. Comparative assessment of the antimicrobial susceptibility of Staphylococcus aureus isolates from bovine mastitis in biofilm versus planktonic culture. J. Journal of Veterinary Medicine B, Infectious Diseases and Veterinary Public Health, Berlin, v. 53, n. 7, p. 326-332, 2006b.

MELCHIOR, M. B.; VAARKAMP, H.; FINKGREMMELS, J. Biofilms: a role in recurrent mastitis infections? The Veterinary Journal, Atlanta, v. 171, n. 3, p. 398-407, 2006a.

MELCHIOR, M. B.; VAN OSCH, M. H. J.; GRAAT, R. M.; VAN DUIJKEREN, E.; MEVIUS, D. J.; NIELEN, M.; GAASTRA, W.; FINK-GREMMELS, J. Biofilm formation and genotyping of Staphylococcus aureus bovine mastitis isolates: evidence for lack of penicillinresistance in Agr-type II strains. Veterinary Microbiology, Barcelona, v. 137, n.1-2, p. 83-89, 2009.

MELCHIOR, M. B., M. H. J. VAN OSCH, T. J. G. M. LAM, J. C. M. VER-OIJ, W. GAASTRA, J. FINKGREMMELS. Extended biofilm susceptibility assay for Staphylococcus aureus bovine mastitis isolates: evidence for association between genetic makeup and biofilm susceptibility. Journal of Dairy Science, Madison, v. 94, n.12, p. 5926-5937, 2011. 
MELO, P. C.; FERREIRA, L. M.; NADER-FILHO, A.; ZAFALON, L. F.; VICENTE, H. I. G. Análise fenotípica e molecular da produção de biofilmes por estires de Staphylococcus aureus isoladas de casos de mastite subclínica bovina. Bioscience Journal, Uberlândia, v. 28, n. 1, p. 94-99, 2012.

NATIONAL MASTITIS COUNCIL. Microbiological procedures for the diagnosis of bovine udder infection and determination of milk quality. $4 \mathrm{t}^{\mathrm{h}}$ ed. Verona: NMC, 2004. 47 p.

NETTO, D. P.; LOPES, M. O.; OLIVEIRA, M. C. S.; NUNES, M. P.; MACHINSKI JUNIOR, M.; BOSQUIROLI, S. L.; BENATTO, A.; BENINI, A.; BOMBARDELLI, A. L. C.; VEDOVELLO FILHO, D.; MACHADO, E.; BELMONTE, I. L.; ALBERTON, M.; PEDROSO, P. P.; SCUCATO, E. S. Levantamento dos principais fármacos utilizados no rebanho leiteiro do Estado do Paraná. Acta Scientiarum. Animal Sciences, Maringá, v. 27, n. 1, p. 145-151, 2005.

OLIVEIRA, A. A. F. MOTA, R. A., SOUZA, M. I, SÁ, M. E. P. Perfil de sensibilidade antimicrobiana in vitro frente a amostras de Staphylococcus spp isoladas de mastite subclínica bovina, no agreste meridional de Pernambuco. A Hora Veterinária, Porto Alegre, v. 22, n. 127, p. 8-10, 2002.

RABELLO, R. F.; SOUZA, C. R. V. M.; DUARTE, R. S.; LOPES, R. M. M.; TEIXEIRA, L. M.; CASTRO, A. C. D. Characterization of Staphylococcus aureus Isolates ecovered from Bovine Mastitis in Rio de Janeiro, Brazil. Journal of Dairy Science, Madison, v. 88, n. 9, p. 32113219, 2005.

RADEMAKER, J. L. W.; DE BRUIJN, F. J. Characterization and classification of microbes by REPPCR genomic fingerprinting and computer-assisted pattern analysis, In: CAETANO-ANOLLÉS, G.; GRESSHOFF, P. M. (Ed.). DNA Markers: protocols, applications, and overviews. New York: J. Wileyand Sons, 1997. p. 151-171.

RAJALA-SCHULTZ, P. J.; SMITH, K. L.; HOGAN, J. S.; LOVE, B. C. Antimicrobial susceptibility of mastites pathogens from first lactation and older cows. Veterinary Microbiology, Barcelona, v. 102, n. 1-2, p. 33-42, 2004.
SABOUR, P. M.; GILL, J. J.; LEPP, D.; PACAN, J. C.; AHMED, R.; DINGWELL, R.; LESLIE, K. Molecular typing and distribution of Staphylococcus aureus isolates in eastern canadian dairy herds. Journal of Clinical Microbiology, Barcelona, v. 42, n. 8, p. 3449-3455, 2004.

SCHWARZ, S.; SILLEY, P.; SIMJEE, S.; WOODFORD, N.; VAN DUIJKEREN, E.; P. JOHNSON,A.; GAASTRA, W. Assessing the antimicrobial susceptibility of bacteria obtained from animals. Veterinary Microbiology, Barcelon, v. 141, n. 1-2, p. 1- 4, 2010.

SEARS, P. M.; SMITH, B. S.; ENGLISH, P. B.; HERER, P. S.; GONZALEZ, R. N. Shedding pattern of Staphylococcus aureus from bovine intramammary infections. Journal of Dairy Science, Madison, v. 73, n. 10, p. 2785-2790, 1990.

TENHAGEN, B. A.; KO STER, G.; WALLMANN, J.; HEUWIESER, W. Prevalence of mastitis pathogens and their resistance against antimicrobial agents in dairy cows in Brandenburg, Germany. Journal of Dairy Science, Madison, v. 89, n. 7, p. 2542-2551, 2006.

UNAKAL, C. G.; KALIWAL, B. B. Prevalence and antibiotic susceptibility of Staphylococcus aureus from bovine mastitis. Veterinary World, Gujarat, v. 3, n. 2, p. 65-67, 2010.

VASUDEVAN, P.; NAIR, M. K. M.; ANNAMALAI, T.; VENKITANARAYANAN, K. S. Phenotypic and Genotypic characterization of bovine mastitis isolates of Staphylococcus aureus for biofilm formation. Veterinary Microbiology, Barcelona, v. 92, n. 1-2, p. 179-185, 2003.

WAAGE, S.; MORK, T.; ROROS, A.; AASLAND, D.; HUNSHAMAR, A.; ODEGAARD, S. A. Bacteria associated with clinical mastitis in dairy heifers. Journal of Dairy Science, Madison, v. 82, n. 4, p. 712-719, 1999.

ZAFALON, L. F; ARCARO, J. R. P.; NADER FILHO, A.; FERREIRA, L. M.; CASTELANI, L.; BENVENUTTO, F. Investigação de perfis de resistência aos antimicrobianos em Staphylococcus aureus isolados na ordenha de vacas em lactação. Revista do Instituto Adolfo Lutz, São Paulo, v. 67, n. 2, p. 118-125, 2008.

ZANELA, M. B.; FISCHER, V.; RIBEIRO, M. E. R.; STUMPF JUNIOR, W.; ZANELA, C.; MARQUES, L. T.; MARTINS, P. R. G. Qualidade do leite em sistemas de produção na região Sul do Rio Grande do Sul. Pesquisa Agropecuária Brasileira, Brasília, v. 41, n. 1, p. 153-159, 2006. 